\title{
Research on Intonation Teaching for Students of Japanese Major in Jingdezhen Ceramic Institute
}

\author{
Yu Wu, Danyu Wu
}

School of International Studies, Jingdezhen Ceramic Institute, Jingdezhen, 333403, China

Keywords: Japanese major, Japanese teaching, intonation teaching, Pronunciation teaching, Jingdezhen Ceramic Institute

\begin{abstract}
With the increasing exchanges between China and Japan, the Japanese language in colleges and universities is heating up. The scale gap between Japanese teaching and the first foreign language teaching in colleges and universities has gradually narrowed. After several decades of development, the number of colleges conducting the Japanese major teaching in China has reached 381 in 2016. The number of Japanese learners has also risen year by year. Even in many universities, the development of Japanese as the second language teaching is booming. Universities that offer in Japanese language courses as the second language are all over the country. The number of students studying the Japanese language as the second language far exceeds the number of students studying the Japanese language as first foreign language. The curriculum is also diversified. Some universities have reached quite a depth in the second foreign language course.
\end{abstract}

\section{Current Teaching Situation of College Japanese in Jingdezhen Ceramic Institute}

The author has conducted the investigation of Japanese pronunciation learning for many times in the teaching experience in recent years for the professional Japanese learners. The main content and main problems are shown as follows.

\subsection{Late start of Pronunciation Teaching and Severe Interference of Mother Dialects}

For Japanese beginners who have just entered the university, they mainly use the Mandarin and their native dialect before contacting with the Japanese language. In the initial Japanese learning, many students were easily disturbed by such factors as the pronunciation of the dialect and native language. There are many of them which are lack of the differences between the retroflex and non-retroflex or the differences between the front nasals and back nasals throughout the different dialects in many locations of China. The Japanese learning statistical data of Jingdezhen Ceramic Institute is shown in Table 1.

Table 1. Japanese learning statistical data of Jingdezhen Ceramic Institute

\begin{tabular}{|c|c|c|}
\hline Learning difficulty & Students fully mastering it & Students cannot fully master it \\
\hline $\begin{array}{c}\text { Voiceless consonant and } \\
\text { voiced consonant }\end{array}$ & $29.8 \%$ & $70.2 \%$ \\
\hline Promote tone & $51.2 \%$ & $48.3 \%$ \\
\hline Difficult tone & $58.0 \%$ & $42.0 \%$ \\
\hline Long tone & $51.6 \%$ & $48.4 \%$ \\
\hline Intonation & $38.7 \%$ & $61.2 \%$ \\
\hline Japanese pronunciation & $62.9 \%$ & $37.1 \%$ \\
\hline
\end{tabular}

Among the students of Japanese majors in Jingdezhen Ceramic Institute, many students have come 
from the areas with sever dialect such as Sichuan, Hunan and so on. For many students in Hunan, the voiceless consonant, the voiced consonant, the promote tone, the Long tone, the beat and the Intonation of the fifty tones are always big headaches.

The majority of students at Jingdezhen Ceramic Institute come from the dialect areas. It leads to a general deviation of the pronunciation of some of the students' words, or the odd pronunciation of certain words, which is difficult to correct.

According to the statistical data, Japanese pronunciation is difficult for most professional Japanese learners. Compared with the other two aspects of linguistics, which are the vocabulary and grammar, the theory research and practice at home and abroad on this aspect is obviously deficient. For the students coming from these areas, learning Japanese of these students are much more difficult than other students.

For the lower grade students, whether the pronunciation foundation is sound or not plays a decisive role in Japanese intensive reading study. If the students can't pronounce it, it will cause serious influence on the memory, reading and listening of the intensive reading in the future.

\subsection{Single Teaching Model and Low Attention Degree of Teachers}

Due to the restriction of traditional teaching ideas, the Japanese intensive reading courses of the students of junior grade learning Japanese often adopt the traditional teaching model. It is a kind of teaching model which is mainly based on mainly teachers' teaching with students' imitation as the supplement.

In this teaching model, some teachers do not pay enough attention to the pronunciation, but pay a lot attention on the grammar teaching. Some Japanese teachers imitate English teaching in senior high school. They only teach the grammar and do not practice any listening.

Due to the small number of Japanese teachers, many Japanese teachers have a quietly heavy teaching task. Some teachers just want to complete the task of teaching grammar, and ignore the pronunciation. This kind of "passive" teaching model is not only bad for students to absorb knowledge, but also easy to make students feel resentful.

Through the investigation of low grade students in recent years, the author found that the practice of blindly echo what the books say would decrease the participation of students. It cannot exert the subjective initiative of the students, leading to the unsatisfied teaching effect. Students who are lack of the autonomous learning awareness in Japanese pronunciation will have a bade mastery of the Japanese pronunciation. The students don't have the review habits, leading to the forgetting. The students will get half the results with twice the effort under the teaching model.

\subsection{Old-fashioned Teaching Materials and Shallow Research Depth}

Compared with the phonetic research of specialized Japanese teaching, the related papers and works of pronunciation teaching of college Japanese are obviously deficient. The teaching content is too rigid and the teaching effect is poor.

Especially for the current Japanese intensive reading class of low grades, the main teaching contents are composed of main word teaching with grammar teaching as supplement. Taking a look at the teaching content of Japanese intensive reading materials in the main universities in China, it is generally relatively old and lacks innovation. Many words are difficult to link up with current affairs and life. It leads to boring motion and low enthusiasm of the students. The quality of teaching has also declined.

\section{Countermeasures of current teaching situation of Japanese intonation in Jingdezhen Ceramic Institute}

The Japanese major of Jingdezhen Ceramic Institute has been established for more than ten years. At present, the teaching achievement of the Japanese major of Jingdezhen Ceramic Institute has been among the best institutes in Jiangxi province.

At the beginning, the Japanese intensive reading teaching of the institute is not prominent, 
especially in Japanese intensive reading teaching of the low grades. After that, the Jingdezhen Ceramic Institute has integrated the intonation teaching into the Japanese intensive reading teaching of the low grades, achieving good results. The students' abilities have been improved.

As a teacher of Japanese major in Jingdezhen Ceramic Institute, the author carried out the teaching reform based on summing up the experience and practice of his predecessors and his own teaching experience. After teaching practice of seventy-five students from 2012 to 2014, we have studied the importance and influence of pronunciation teaching in Japanese intensive reading class in the past three years. The following are the relevant results and statistics obtained through practice in the past three years.

\subsection{Intonation Teaching Content and Teaching Materials Selection}

The correct pronunciation is the basis of primary Japanese intensive reading teaching, and an introduction to Japanese students' learning. We do not expect the phonetic teaching will improve the students' level of Japanese to the level of speaking fluently as the mother language, but hope to improve the speech increase students' oral Japanese ability and to promote the comprehensive improvement of Japanese listening reading and writing in the new teaching model of elementary Japanese intensive reading course.

In the use of teaching materials, the author adopted Japanese Phonetics Course pressed by Shanghai Foreign Language Education Press.

After three years of teaching, according to the contents of the book, we improve the level of students' Japanese phonetics from the perspectives of Japanese pronunciation, intonation, tone, accent and other aspects. The main methods are oral training, group discussion, speech and so on.

\subsection{Research Results}

Phonetics teaching experiments began from the freshmen in 2012-2014. In the first semester of freshmen's learning Japanese, the students will be integrated into the teaching of phonetics in the teaching of Japanese intensive reading. The training is based on basic pronunciation teaching, accent training, dialogue exercise and so on. After a semester of training and statistics, a total of one hundred and forty-five freshmen in the three years conducted the speech teaching and special training. As table 2 shows, the following statistical results can be obtained from a questionnaire survey.

Table 2. Table of the help degree of the new teaching model

\begin{tabular}{|c|c|c|c|c|}
\hline Results & Huge help & A little help & Hard to say & No help \\
\hline Students & 136 & 5 & 4 & 0 \\
\hline & & & & \\
Percentage & $93.80 \%$ & $3.50 \%$ & $2.70 \%$ & $0 \%$ \\
\hline
\end{tabular}

The Table 3 is about the help of the integration of the intonation teaching into the Japanese intensive reading teaching.

Table 3. Table of the help aspects of the new teaching model

\begin{tabular}{|c|c|c|c|c|}
\hline Content & $\begin{array}{c}\text { Make the } \\
\text { language authentic }\end{array}$ & $\begin{array}{c}\text { Enhance } \\
\text { self-confidence }\end{array}$ & $\begin{array}{c}\text { Change the } \\
\text { ideas }\end{array}$ & $\begin{array}{c}\text { Communicate } \\
\text { fluently }\end{array}$ \\
\hline Students & 85 & 42 & 14 & 4 \\
\hline Percentage & $58.6 \%$ & $28.9 \%$ & $9.8 \%$ & $2.7 \%$ \\
\hline
\end{tabular}

The Table 4 is about whether to continue to integrate the intonation teaching into the Japanese intensive reading teaching. 
Table 4. Table of whether to continue the new teaching model

\begin{tabular}{|c|c|c|c|c|}
\hline Results & Very necessary & Necessary & Hard to say & Unnecessary \\
\hline Students & 140 & 4 & 1 & 0 \\
\hline Percentage & $96.6 \%$ & $2.7 \%$ & $0.7 \%$ & $0.0 \%$ \\
\hline
\end{tabular}

\section{Implications}

\subsection{Establish Good Language Environment to Stimulate Students’ Interest}

To improve the students' learning efficiency, it is very important to create a good teaching language environment. It requires our teachers to create a good environment for students to voice teaching in the daily teaching process, and strive to cultivate students' initiative to speak Japanese interest. The teachers should have a good emotional communication with students. Only the students love the Japanese language, they can make great efforts to learn it. As a teacher of Japanese major, it is necessary to find out the teaching orientation in daily teaching, and put more emphasis on the role and function of Japanese phonetics teaching in intensive reading course. For example, in the actual teaching of fifty tone maps, teachers should pay attention to the students' understanding of Chinese characters in the evolution of phonetics. Teachers can stimulate students' interest and improve their learning efficiency from the course of their evolution.

\subsection{Improve Teaching Methods to Enhance Teaching Effectiveness}

Due to the restriction of traditional teaching ideas, the Japanese intensive reading courses of the students of junior grade learning Japanese often adopt the traditional teaching model. It is a kind of teaching model which is mainly based on mainly teachers' teaching with students' imitation as the supplement. It makes the students feel boring with the low efficiency. Therefore, we adopted the student-cantered model of the course teaching in the teaching practice.

For example, in the teaching process of Japanese pronunciation words, we required the students taught themselves. The questions and answers among the students can help them to correct their mistakes. This approach can not only improve students' enthusiasm and self-confidence, but also can improve their oral Japanese ability. With the accumulation of students' vocabulary, we require students to make impromptu or non-impromptu speeches in the middle and late stages of their first grade. Through the above methods, we can effectively create a good rich voice environment for the students. It allows the students to exert a subtle interest in the Japanese language, which is conducive to the improvement of students' Japanese level.

\section{Conclusion}

Japanese intensive reading is the main content of college Japanese teaching. The mastery degree of the students of the intensive reading courses directly affects their Japanese language proficiency.

Japanese pronunciation is the enlightenment and basic stage of Japanese education, which plays a very important role. The Japanese-Language Proficiency Test strengthened the listening examination in 2010. The difficult degree of the listening increased a lot and the score of the listening examination accounted for about one third of the total score. Moreover, the content of the listening examination is closely related to the daily life. It requires the students to read more news reports and articles of the original Japanese edition to intensify the practice. The significance of the Japanese pronunciation is remarkable.

We should abandon the traditional poon-feeding teaching method of Japanese intensive reading teaching. While paying attention to the pronunciation teaching, teachers should try to promote students' oral communication and exercise their interest. At the same time, teachers should constantly sum up the teaching experiences, and timely adjust the teaching methods to find the teaching methods 
belonging to the college and the major. At the same time of imparting knowledge, the teachers should comprehensively train the students' diversified abilities of listening, speaking, reading and writing to make their due contribution to the overall improvement of the Japanese teaching level.

\section{References}

[1] Peng Daoxiu. Current Situation of Square Fitness Dance in the Urban Areas of Hubei Province and Its Development Tendency [J]. Journal of Yangtze University (Natural Science Edition), 2016, 13(13): 62-65.

[2] Kuang Liehui. Study on the Development of Square Fitness Dance from Visual Angle of Harmony [J]. Journal of Beijing Sport University, 2014, 37(4): 32-37.

[3] Cao Jiwei, Yuan Yuan. A Study on Dilemma and Path of the Development of Square Dance in the Background of the Nation-wide National Fitness Strategy [J]. Bulletin of Sport Science \& Technology, 2017, 25(2): 99-100+125.

[4] Yao Xia. On the Composition of Mongolians Square Fitness Dance [J]. Wushu Studies, 2016, 1(12): 97-100+103. 